Article

\title{
Microbial Contamination Survey of Environmental Fresh and Saltwater Resources of Upolu Island, Samoa
}

\author{
Michael A. Ochsenkühn ${ }^{1, *(\mathbb{C})}$, Cong Fei ${ }^{1}$, Odmaa Bayaara ${ }^{1}$, Emarosa Romeo ${ }^{2}$, Patila Amosa ${ }^{3}$, \\ Youssef Idaghdour ${ }^{1}$, Gary Goldstein ${ }^{4}$, Timothy G. Bromage ${ }^{5}$ (D) and Shady A. Amin ${ }^{1, *(D)}$ \\ 1 Biology Program, Division of Science, New York University Abu Dhabi, Abu Dhabi P.O. Box 129188, \\ United Arab Emirates; cf2290@nyu.edu (C.F.); ob733@nyu.edu (O.B.); yi3@nyu.edu (Y.I.) \\ 2 Hydrology Division, Ministry of Natural Resources and Environment, Level 3, Tui Atua Tupua Tamasese 13 \\ Efi Building (TATTE), Sogi., P.O. Private Bag, Apia 1338, Western Samoa; emarosa.romeo@mnre.gov.ws \\ 3 Faculty of Science, National University of Samoa, Apia P.O. Box 1622, Western Samoa; p.amosa@nus.edu.ws \\ 4 Department of Prosthodontics, New York University College of Dentistry, 345 East 24th Street, \\ New York, NY 10010, USA; gary.goldstein@nyu.edu \\ 5 Department of Molecular Pathobiology, New York University College of Dentistry, 345 East 24th Street, \\ New York, NY 10010, USA; tim.bromage@nyu.edu \\ * Correspondence: MAO13@nyu.edu (M.A.O.); samin@nyu.edu (S.A.A.)
}

\section{check for} updates

Citation: Ochsenkühn, M.A.; Fei, C.; Bayaara, O.; Romeo, E.; Amosa, P.; Idaghdour, Y.; Goldstein, G.; Bromage, T.G.; Amin, S.A. Microbial Contamination Survey of Environmental Fresh and Saltwater Resources of Upolu Island, Samoa. Environments 2021, 8, 112. https://doi.org/10.3390/ environments 8110112

Academic Editor: Silvia Quadroni

Received: 16 May 2021

Accepted: 18 October 2021

Published: 25 October 2021

Publisher's Note: MDPI stays neutral with regard to jurisdictional claims in published maps and institutional affiliations.

Copyright: (c) 2021 by the authors. Licensee MDPI, Basel, Switzerland. This article is an open access article distributed under the terms and conditions of the Creative Commons Attribution (CC BY) license (https:/ / creativecommons.org/licenses/by/ $4.0 /)$.
Abstract: Analysis of microbe diversity in freshwater resources and nearshore seawater samples of Upolu Island was performed to investigate the distribution of harmful bacteria. For this, 124 samples were collected from 23 river systems, two volcanic lakes, and 45 locations inside and outside the barrier reef of Upolu Island, Samoa. Physicochemical parameters for general water quality, detection of coliform bacteria and 16S rRNA amplicon sequencing were performed on all samples. Fecal indicator bacteria (FIB) testing indicated a wide distribution of coliform bacteria in all sampled freshwater sites with evidence of fecal coliform in most locations. Importantly, evidence of coliform bacteria was found in most seawater samples inside and along the reef, apart from those samples taken $\sim 20 \mathrm{~km}$ offshore. Illumina 16S rRNA amplicon sequencing of the V4 hypervariable region confirmed the presence of various types of harmful bacterial species, namely from the Enterobacteriaceae, Enterococcae, Streptococcaceae, and Vibrionacea families. By combining the sensitivity of FIB testing and next-generation sequencing, we were able to show the extent of potential contaminations in fresh and seawater samples and simultaneously identify the potential pathogenic bacterial genera present. The wide distribution of potential harmful bacteria from river runoff or direct sewage dumping has an impact on human health, leading to many skin and intestinal diseases, and is potentially detrimental to coral reef community health.

Keywords: microbes; freshwater; saltwater; diversity; fecal; biosecurity; Samoa; coral reefs

\section{Introduction}

Anthropogenically-induced microbial contamination of freshwater resources results in $\sim 2.2$ billion people lacking adequate access to safe drinking water. This problem leads to an increasing rate of child mortality and severe diseases [1]. Anthropogenic activities also pose a danger to coastal marine habitats that experience negative pressure from terrestrial runoff, endangering marine ecosystems, such as coral reefs [2] as well as coastal populations [3]. Mixing and accumulation of pathogens in coastal areas is also influenced by physical properties. Within protective barrier reefs, such as around Upolu Island, Samoa, water flow and dilution are restricted and, as a consequence, contaminants significantly accumulate, as shown in a recent study on the Great Barrier Reef [4]. As a result, acute infections from direct contact with waters contaminated with microbial pathogens that are able to survive in nutrient-rich fresh and sea waters occur frequently [5].

Anthropogenic activities often lead to changes in the equilibrium of aquatic systems. The effects range from increases in heavy metal concentrations, chemical waste, runoff 
from agriculture of pesticides and fertilizers, to proliferation of pathogenic bacteria from sewage, which are all detrimental to natural flora and fauna [6-8]. Natural disasters and climate change cause severe droughts and heavier rainfalls which result in soil depletion and uncontrolled waste discharges, increasing the severity of negative impacts on aquatic systems $[9,10]$. To mitigate the adverse effects on human and environmental health, the presence and distribution of contaminants needs to be monitored frequently to inform water resource management and enable necessary actions.

The Independent State of Samoa experienced recent outbreaks of waterborne diseases that led to severe diarrhea and typhoid-like symptoms among its population [11]. Local communities partly rely on freshwater from rivers and streams to complement their drinking water supply and, accordingly, are potentially directly exposed to pathogenic microbes. An additional challenge for rural areas is the storage of sewage in septic tanks. These often leak pathogens into freshwater resources and coastal waters, either because of poor maintenance or faulty construction [12-15]. A recent study performed by Amosa et al. of two Samoan river systems from July 2015 to February 2016 found an increase in fecal coliform bacteria during the wet season months from November to February. According to detailed surveys of the area, they suggested human sewage and agricultural runoff as the cause for increased bacterial contaminants [16]. Although marker pathogens, like fecal indicator bacteria (FIB), show a good correlation with waterborne illness cases [17], only a weak correlation with enteric pathogens can be made [18]. FIB detection, though highly sensitive, is only sensitive to a select group of pathogenic bacteria. Next-generation sequencing, which in recent years has become more affordable, allows the determination of the whole spectrum of microbial diversity, providing insight into bacterial pathogens, including FIBs.

This work aimed to identify microbial contaminants in fresh and seawater of Upolu island, Samoa, compare their relative abundance and diversity in fresh and salt waters around the island, and achieve a baseline survey for water biosafety. Water catchments, rivers, lakes and coastal waters were sampled at the start of the 2019 wet season. The massive sampling effort was complemented with the application of water sensors, quick and targeted coliform detection, and examination of the microbial community diversity using 16S rRNA amplicon sequencing. The resulting data enabled the construction of an overview of contaminated areas and the most prevalent potentially pathogenic microbes present, which we hope will provide a baseline assessment for use in future water management efforts.

\section{Materials and Methods}

\subsection{Study Area and Sampling}

Freshwater and saltwater resources sampling took place in Upolu Island, Samoa, through 1-15 December 2019, as reported in Rabieh et al. 2020 [6]. Five teams were composed of personnel from the Samoan Ministry of Natural Resources and Environment personnel and the Faculty of Science, National University of Samoa. The effort was also supported by seawater sampling by AquaSamoa (Apia, Samoa), with boat teams and SCUBA divers. Field teams were dispatched to each of Upolu Island's northern, eastern, southern, and western regions, taking samples from 24 rivers, two volcanic lakes, and one dam. Boat teams collected samples from 45 sites, circumnavigating the island of Upolu. The teams were supplied with 500-mL glass vessels (wide mouth preserving jars), which were rinsed thoroughly with hot distilled water, disinfected with $70 \%$ ethanol and rinsed again with distilled water. All freshwater samples were collected in parallel within six days. Surface water was collected at river banks and lake shores directly by scooping with the sampling vessels using nitrile gloves. Seawater sampling was delayed due to a three-day state of emergency during the sampling period and was undertaken over ten days in total. Seawater samples were collected by SCUBA at 10-m depth or as low as the site allowed in order to minimize the UV degradation of bacteria in the surface. Vessels were filled with distilled fresh water at the surface and brought to depth. The vessels were cleared 
out at depth with pressured air and allowed to fill, and were then sealed and brought to the surface. All samples were stored in a cool and dark container until arrival at the laboratory, where samples were stored at $0-4{ }^{\circ} \mathrm{C}$ until processing as follows. In all, out of the 88 samples that were analyzed in this study, 54 freshwater (FW) samples were collected from river systems and catchments and 34 seawater (SW) samples were collected from inshore and offshore locations. Samples were taken from five different types of locations, FW samples from Upstream (A), Midstream (B), Rivermouth/Estuary (C) sites and SW samples from Inside lagoon (D) and Outside lagoon (E). Inside and outside denotes within the barrier reef and outside the barrier reef. SW samples collected from sites without an extensive protective barrier reef were labeled as outside lagoon.

\subsection{Coliform Bacteria Detection}

Coliform bacteria in the samples were detected using the Colilert Test Kit (IDEXX Laboratories, Westbrook, ME, USA) on the same day as the sampling. The assay combines rapid detection within $24 \mathrm{~h}$ of coliform FIB, which are bacterial indicators of waste from animal or human sources, and highly sensitive detection of bacteria $(>1$ bacterial cell/100 mL sample), such as harmful fecal coliform bacteria like Escherichia coli. The test kit specifically targets coliform bacteria and provides evidence of fecal (harmful) coliforms by observing growth and enzymatic activities. According to the manufacturer's protocol, $100 \mathrm{~mL}$ of the collected water samples were incubated at $35 \pm 0.5^{\circ} \mathrm{C}$ for $24 \mathrm{~h}$ in sterilized transparent plastic containers with the Colilert Test Kit. Observed bacterial growth after $18 \mathrm{~h}$ indicates the presence of coliform bacteria. Further, to detect fecal coliform a UV-light torch was used to screen the samples for fluorescence, indicating the presence of $>1$ fecal bacterial cells per $100 \mathrm{~mL}$ sample after $24 \mathrm{~h}$. Daily positive and negative controls were established with live fecal matter suspension in water and distilled water, respectively.

\subsection{Sample Filtration for DNA Sequencing}

To recover DNA for microbial community assessment of the samples the leftover $400 \mathrm{~mL}$ were kept at $\sim 0-4{ }^{\circ} \mathrm{C}$ until same day filtration through $0.2-\mu \mathrm{m}$ sterile Sterivex cartridges (EMD Millipore, Darmstadt, Germany) using a Masterflex peristaltic pump (Masterflex, Gelsenkirchen, Germany) was carried out. Sterivex cartridges were then filled with $\sim 4 \mathrm{~mL}$ of RNAlater (Ambion, Austin, TX, USA) tissue storage reagent to preserve DNA viability and were sealed by applying a plug made of Blu-Tak and parafilm wrapping. The filters were stored at $4{ }^{\circ} \mathrm{C}$ until arrival at NYUAD campus ( $\sim$ days), where the samples were stored at $-80^{\circ} \mathrm{C}$ until DNA extraction.

\subsection{Water Parameter Measurements}

Physicochemical parameters were measured for the water samples using a YSI ProPlus multimeter (Xylem Inc., Rye Brook, NY, USA) connected to a Pro Series Quatro sensor holder. Samples were measured upon return to the lab once microbes were removed by filtration. The sensors for freshwater included $\mathrm{pH}$, dissolved oxygen (DO) in $\mathrm{mg} / \mathrm{L}$, oxidation-reduction potential (ORP), nitrate levels in $\mathrm{mg} / \mathrm{L}$ and chloride concentration in $\mathrm{mg} / \mathrm{L}$. In the case of the seawater samples, salinity, $\mathrm{pH}, \mathrm{DO}$ and ORP were measured (Table S1). Because samples were not measured immediately upon collection, but rather several hours after, some parameters (mainly DO and ORP) may not accurately represent in-situ values.

\subsection{DNA Extraction, $16 S$ rRNA Sequencing and Data Analysis}

Sterivex filters preserved with the RNAlater solution were drained and opened on one end to remove the filters. The filters were placed into $2.0 \mathrm{~mL}$ reinforced microcentrifuge tubes (Eppendorf, Hamburg, Germany) and two sterile $5.0 \mathrm{~mm}$ stainless steel bead-beating balls were added and kept on ice. For DNA extraction the All-Prep-DNA/RNA extraction kit (Qiagen, Hilden, Germany) was used with the following modifications for the cell lysis protocol. The provided lysis buffer (RLT) was supplemented with $1 \mu \mathrm{L}$ of each: RNase, 
Proteinase K (Promega, Madison, USA) at $1 \mathrm{mg} / \mathrm{mL}$ in MilliQ water (<18.2 M $\Omega$ ), lysozyme ( $1 \mathrm{mg} / \mathrm{mL}$ MilliQ) per $600 \mu \mathrm{L}$. An amount of $600 \mu \mathrm{L}$ of supplemented RLT buffer was added to the filters and incubated at $65{ }^{\circ} \mathrm{C}$ for $30 \mathrm{~min}$. Further, cells were disrupted for 10 min at medium speed with a Tissuelyzer (Qiagen, Hilden, Germany) cell disruptor. Cell debris was removed by centrifugation in a 5425 microcentrifuge (Eppendorf, Hamburg, Germany) at room temperature for $10 \mathrm{~min}$ at $18,000 \times g$. The resulting supernatant was transferred into fresh sterile microcentrifuge tubes and All-Prep-DNA purification was performed according to the manufacturer's instructions.

DNA was eluted in nuclease-free water and preserved at $-80{ }^{\circ} \mathrm{C}$. For sequencing, DNA samples were prepared at 10-50 ng/ $\mu \mathrm{L}$ according to Qubit 2.0 (Thermo Fisher Scientific, Waltham, MA, USA) measurements and were delivered on dry ice to the Carver Biotechnology Center (University of Illinois-Urbana Champagne, Champaign and Urbana, IL, USA) for sequencing. The service included Fluidigim (Fluidigim Co., South San Francisco, CA, USA) library preparation using the hypervariable region V4 515F (new) GTGYCAGCMGCCGCGGTAA and V4 806R (new) GGACTACNVGGGTWTCTAAT primer-pair for $16 \mathrm{~S}$ rRNA amplification, with spiked PhiX as the positive control, and sequenced with MiSeq $2 \times 250$ (Illumina, CA, USA).

The sequencing yielded 88 samples with sufficient reads after FASTQ check and trimming were completed. Sequences were analyzed using the DADA2 Software [19] in R Version 3.6.0. The DADA2 R-script uses raw amplicon sequencing data in FASTA format as the input. Error-correction of the abundances of amplicon sequence variants (ASV) was performed, quality filtered, dereplicated, chimeras removed and endpairs merged. For taxonomic assignment, the sequences were aligned against the SILVA database (release 132) [20]. Chloroplasts, mitochondria, eukaryotes and unknown reads were removed. The 88 samples used for analysis (>1000 reads per sample; negative controls of MilliQ water yielded $<400$ reads) ranged between 2707 and 241,774 reads. Full sequencing and processing statistics can be found in the Supporting Dataset Table 'Dada2 Statistics'. For statistical analysis, the R packages phyloseq [21], vegan [22] and ggplot2 [23] and the Krona Web tool [24] for graphing were used. Maps were plotted with the help of ArcGIS base maps and ArcGIS desktop (ESRI, Redland, CA, USA).

\section{Results}

\subsection{Freshwater and Seawater Physicochemical Parameters}

The complete physicochemical and GPS data for each sample/site can be found in SI Table S1 and the Supporting Datasheets "Seawater and Freshwater Parameters". Measurements of freshwater $\mathrm{pH}$, dissolved oxygen (DO), oxidative reductive potential (ORP) and Nitrate levels are shown in Table 1 . The $\mathrm{pH}$ values ranged from $6.6-8.3 \pm 0.1$, which is within the guidelines for suitable drinking water [25]. The DO ranges varied between $6.1-8.6 \pm 0.2 \mathrm{mg} / \mathrm{L}$ in most samples, which also conforms to the norm for environmental water bodies to allow the survival of fish and indicates a normal oxic environment in freshwater. Low DO was found at Gasegase site 1 (2.1 $\pm 0.2 \mathrm{mg} / \mathrm{L})$, Falefa sites 2 and 3 (3.7 and $4.4 \pm 0.2 \mathrm{mg} / \mathrm{L})$ as well as in the sample taken from Afulilo Dam (5.6 $\pm 0.2 \mathrm{mg} / \mathrm{L})$, which are stressful levels for fish respiration. An elevated oxygen level was measured for Lona Rivermouth $(10.26 \pm 1 \mathrm{mg} / \mathrm{L})$, which was probably caused by increased salinity. ORP, together with DO, are indicators of water quality and with a range from 76-199 $\mathrm{mV}$ lay in a normal range. Nitrate levels were also below the safe drinking water range of $10 \mathrm{mg} / \mathrm{L}$, ranging from 0.01-6.8 mg/L, with three samples exceeding this range, Muliau (Midstream), Taelefaga (Upstream/Midstream), measuring values between $16.8-21.3 \mathrm{mg} / \mathrm{L}$. 
Table 1. Physicochemical parameters overview showing minimum, maximum and median values of FW and SW samples with instrument standard errors $( \pm \mathrm{SE})$ for each measurement.

\begin{tabular}{|c|c|c|c|c|c|}
\hline Freshwater & $\mathrm{DO}^{\#}$ in $\mathrm{mg} / \mathrm{L}$ & $\mathrm{pH}$ & $\mathrm{ORP}^{\$}$ in $\mathrm{mV}$ & $\mathrm{NO}_{3}{ }^{+}$in $\mathrm{mg} / \mathrm{L}$ & $\mathrm{Cl}^{-}$in $\mathrm{mg} / \mathrm{L}$ \\
\hline Minimum & $2.1 \pm 0.2$ & $6.6 \pm 0.1$ & $76.5 \pm 5$ & $0.01 \pm 0.05$ & 2.18 \\
\hline Median & $8.2 \pm 0.2$ & $7.5 \pm 0.1$ & $149.9 \pm 5$ & $0.01 \pm 0.05$ & 8 \\
\hline Maximum & $10.8 \pm 0.2$ & $8.3 \pm 0.1$ & $191.1 \pm 5$ & $20.8 \pm 0.05$ & 8500 \\
\hline Seawater & $\mathrm{DO}^{\#}$ in $\mathrm{mg} / \mathrm{L}$ & $\mathrm{pH}$ & ORP $\$$ & SPC \& & PSU * \\
\hline Minimum & $5.7 \pm 0.2$ & $7.8 \pm 0.1$ & $88.2 \pm 5$ & $51.1 \pm 0.5$ & $33.5 \pm 0.5$ \\
\hline Median & $6.5 \pm 0.2$ & $7.9 \pm 0.1$ & $131.8 \pm 5$ & $53.3 \pm 0.5$ & $35.4 \pm 0.5$ \\
\hline Maximum & $8.1 \pm 0.2$ & $8.0 \pm 0.1$ & $176.3 \pm 5$ & $59.7 \pm 0.5$ & $45.1 \pm 0.5$ \\
\hline
\end{tabular}

" DO = Dissolved oxygen; $\$$ ORP = Oxidative Reductive Potential; \& SPC = Specific conductivity; * PSU = Practical Salinity Unit.

In regard to the seawater samples, the $\mathrm{pH}$ values ranged between $7.9-8.0$ and therefore indicated slightly more acidity than the open ocean average of 8.1. Salinities of the SW samples ranged between 33.5-35.6 PSU, with increased values found at Falesiu and Saoluafata, 45 and 40 PSU, respectively. The DO ranged between $5.7-8.0 \mathrm{mg} / \mathrm{L}$, which can be considered normal for seawater. ORP levels for most $\mathrm{SW}$ samples ranged between 104-184, whereas Leauva, Moataa, and Faleasiu showed slightly lower values (91, 92, and 88 , respectively).

\subsection{Contaminant Estimate with Fecal Indicator Bacteria (FIB)}

For immediate qualitative detection of FIB we used the Colilert Assay Kit. We found that nearly every collected sample, independent of whether the sample was FW or SW, contained coliform bacteria and fecal coliform, as shown in Figure 1. Only three FW samples and one SW sample were free of FIBs (Table 2, Supporting Datasheets "FW- and SW Parameters"). The seawater samples which were not contaminated with coliform bacteria were from the Moataa offshore reef $>20 \mathrm{~km}$ of the coast.

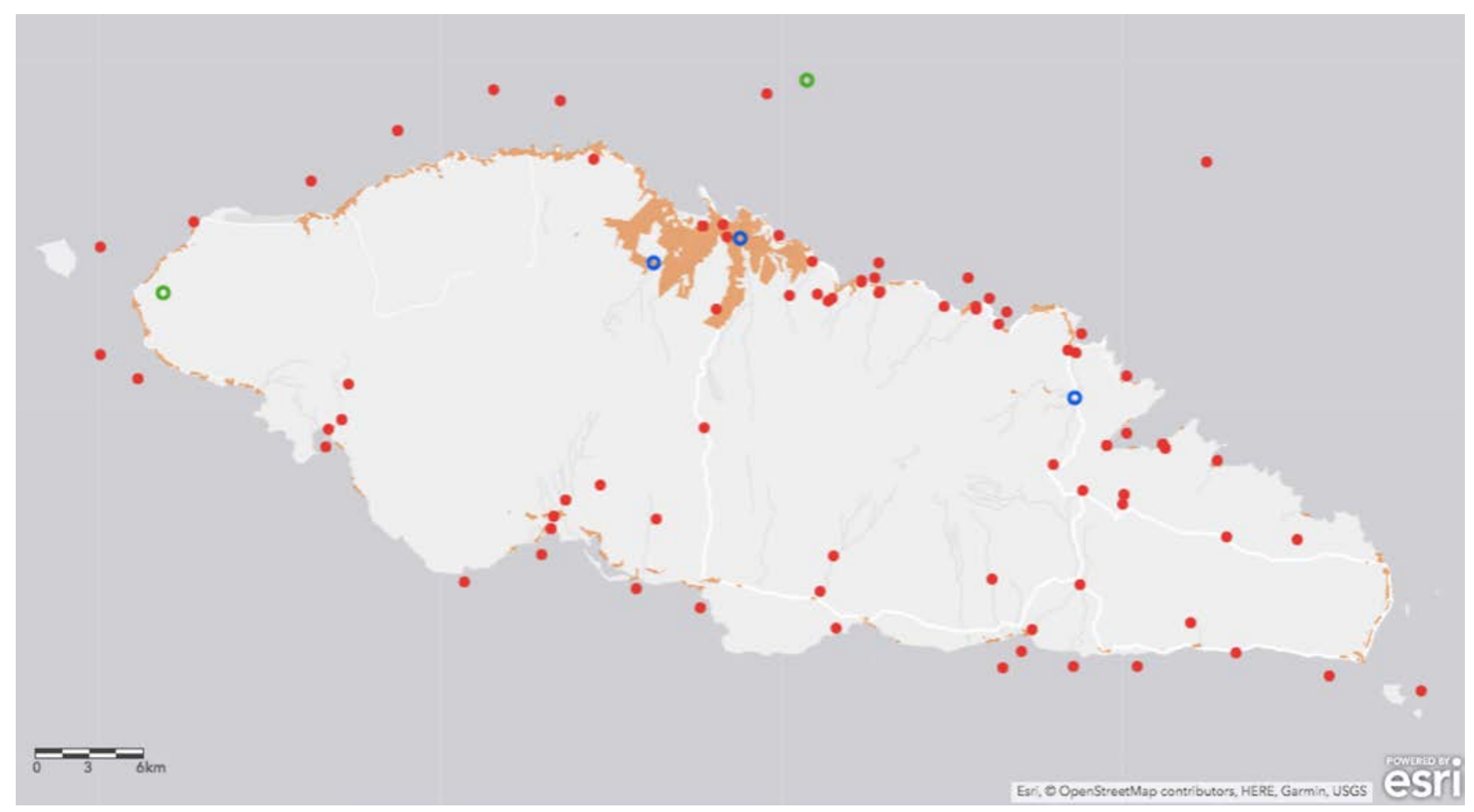

Figure 1. Map of Upolu Island waterways, the distribution of coliform bacteria as tested by Colilert Test Kit. Colored symbols represent sample sites: no coliform bacteria detected (green rings), coliform detected (blue rings) and coliform and $>1$ cell/100 mL fecal E. coli detected (red circles). 
Table 2. Overview of Fresh- and Seawater sample contaminated with $>1$ coliform or fecal coliform bacteria in $100 \mathrm{~mL}$ of water sample.

\begin{tabular}{cccc}
\hline & No. of Samples & Coliform & FIB $>$ 1 Cell/100 $\mathbf{~ m L}$ \\
\hline Freshwater & 54 & 53 & 51 \\
Seawater & 34 & 33 & 33 \\
\hline
\end{tabular}

Sampling of a complete river system at different points between its origin and end allows for contaminant tracing. In this study, coliforms were already present upstream in rivers and were presumably carried downstream, reaching river mouths/estuaries and coastal waters. This observation was common to rivers around the densely populated areas of Apia and in areas of lower population density, like Tiavea, Solosolo, Salelesi, Lepa, Aufaga, Salani and Falease'ela.

\subsection{Microbial Community Biodiversity}

By undertaking $16 \mathrm{~S}$ rRNA sequencing of the hypervariable $\mathrm{V} 4$ region, a total of $\sim 6.2$ million reads ( $\sim 2$ Gbases) of raw data were obtained. After DADA2 processing, $\sim 4.7$ million reads were obtained with read yield per sample varying between 2707 and 241,774 with a median read number of 51,147 reads. Taxonomic alignment to Silva 132 database led to 1336 genera recovered belonging to 479 families, 340 orders, 131 classes and 66 phyla.

The microbial community was analyzed according to sampling locations (Upstream $(n=15)$, Midstream $(n=18)$, Rivermouth $(n=21)$, Inside lagoon $(n=18)$ and Outside lagoon $(n=16))$ and sample type FW and SW. Chao1, an abundance-based diversity index, shows a significantly higher diversity in FW samples compared to SW samples (two tailed $t$-test, $p=0.011$ ) (Figure 2A). The median of the FW diversity increases from upstream to river mouth samples without statistical significance (ANOVA $p>0.05$ ). On the other hand, the Shannon-index, which measures species diversity as an abundance-independent number of different ASVs per sample, shows that FW samples were statistically significantly higher in diversity than SW samples (two-tailed $t$-test, $p=0.023$ ) (Figure 2A).

To compare similarities between samples we used multivariate non-metric multidimensional scaling (NMDS) analysis and the Bray-Curtis distance statistic. FW and SW samples showed a strong distinction, which is expected given that salinity is a major driver of microbial diversity (Figure 2B). Pearson correlation of the samples and Ward clustering of the rarefied data showed a consistent, distinct grouping of FW and SW samples with the aforementioned outliers (Figure S1). Upstream and Midstream, as well as inner and outer reef, samples showed significant clustering in NMDS1 between -0.25 to 0.5. Samples laying in between the two major clusters are from river mouths or estuaries and samples from inside the lagoon are where either river water accumulates or mixing might be impeded. Two of the samples denoted as outside lagoon, which were sampled from southern sites with small barrier reefs or no barrier reef, also seemed to be affected directly by freshwater inputs (Figure 2B).

The phyla of the top 100 ASVs from all samples were composed mainly of Proteobacteria, Bacteriodetes, Cyanobacteria and Actinobacteria (Figure 2C). FW diverged mostly in cyanobacterial reads, decreasing at midstream sites. Both SW samples seem at phyla and class level to be more homogenous. 


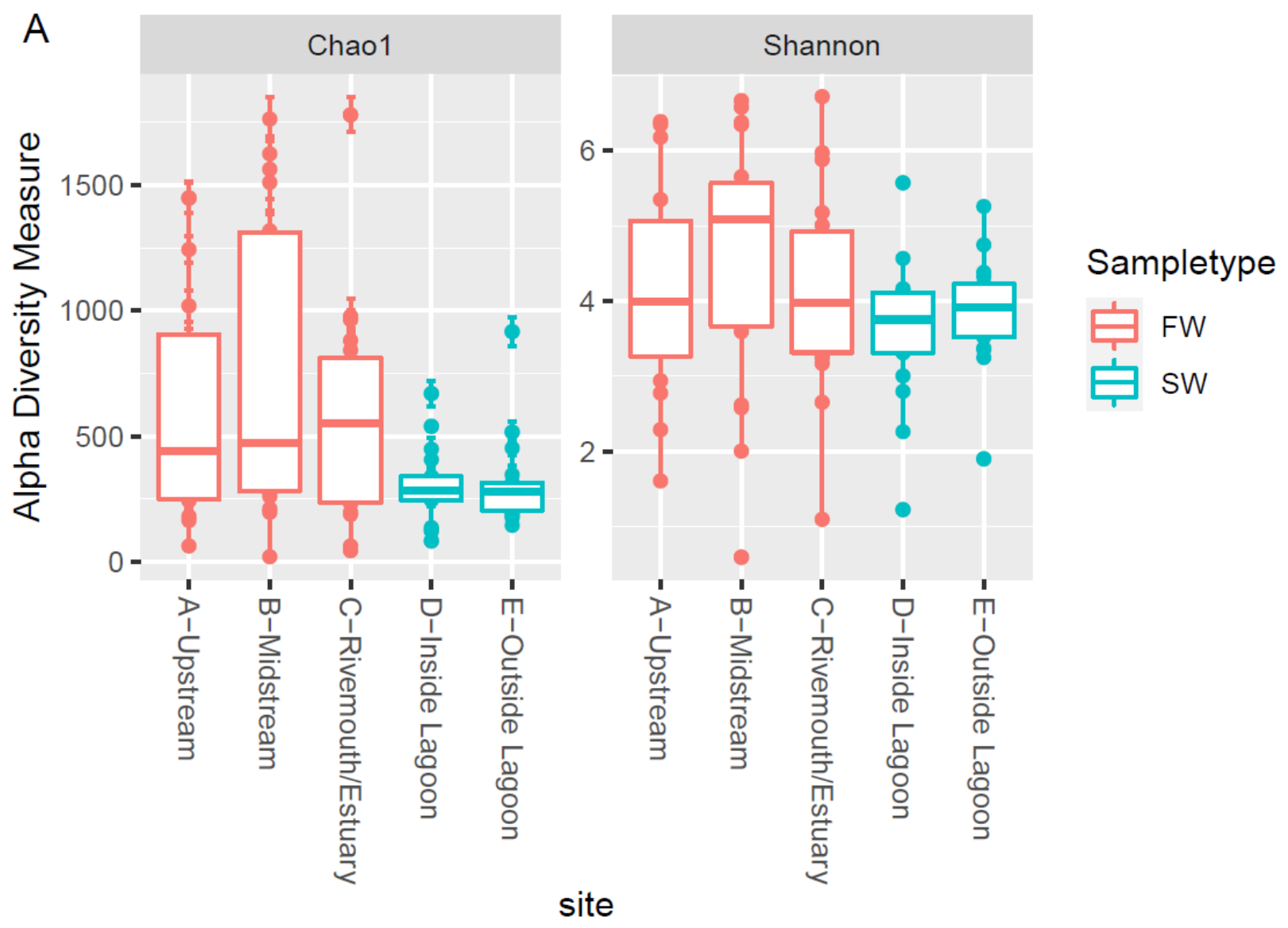

B Bray NMDS

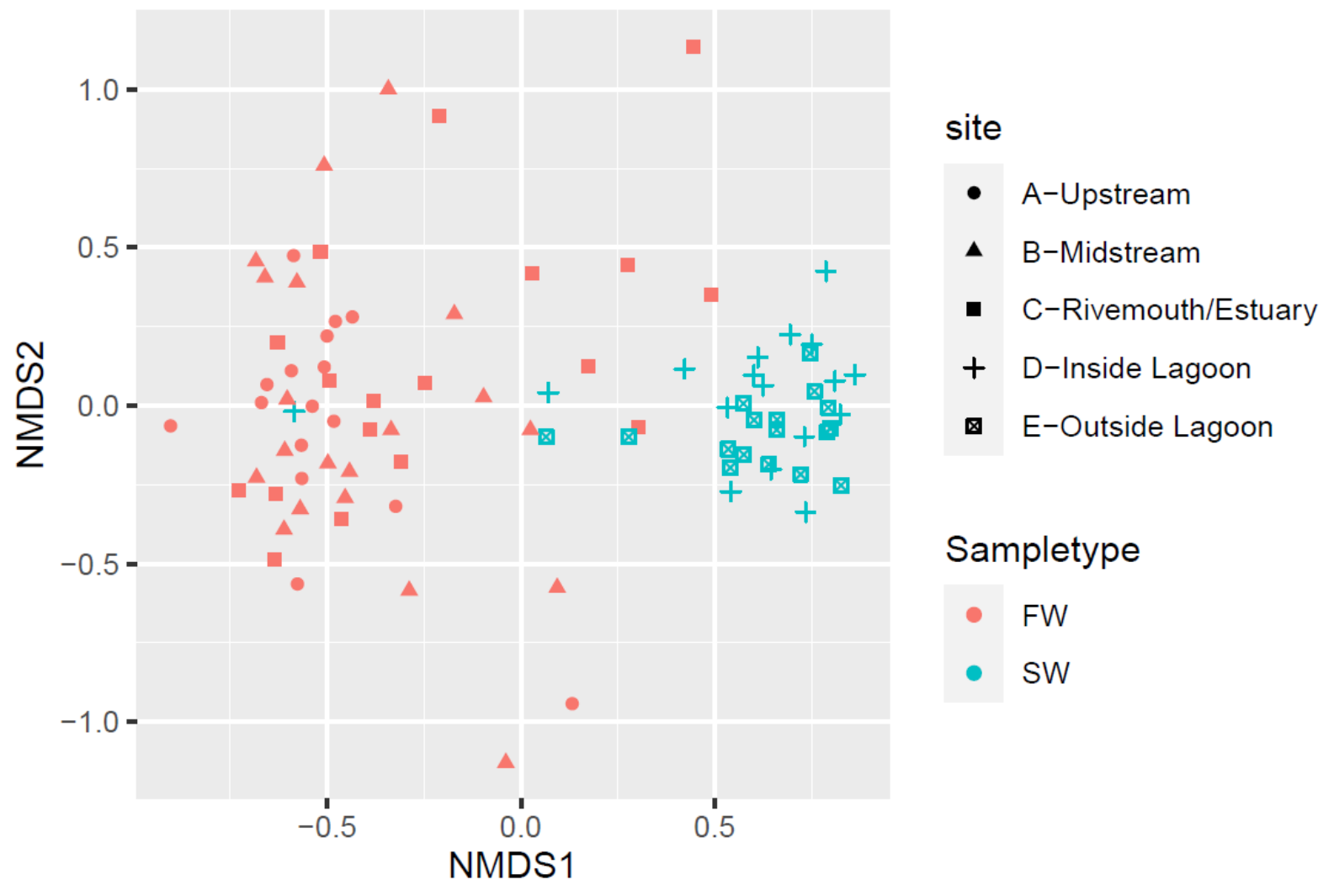

Figure 2. Cont. 

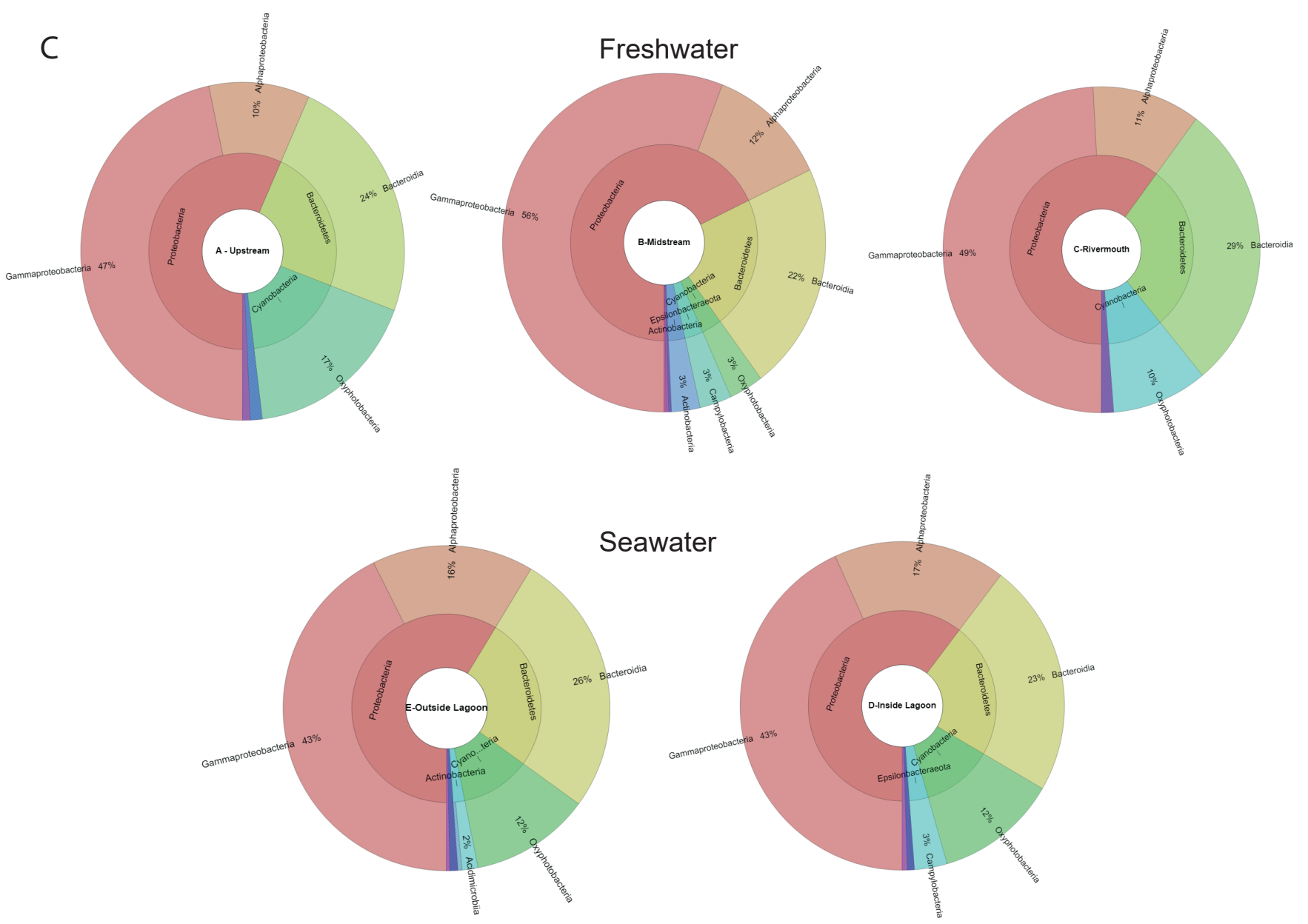

Figure 2. (A) Chao1 and Shannon diversity indices of FW and SW for samples collected at the 5 sampling sites, Upstream-A $(n=15)$, Midstream-B $(n=18)$, Rivermouth-C $(n=21)$, Inside-D $(n=18)$ and Outside lagoon-E $(n=16)$. Differences in FW and SW sample diversity in both metrics are significant (Chao1 $p=0.011$, Shannon $p=0.023$ ). (B) Bray-Curtis NMDS representation of individual sample communities depicts the separation between sample types (FW, SW). (C) Bacterial community composition at phylum and class level for the various sampling sites of the top 100 most abundant ASVs in FW and SW.

\subsection{Distribution of Potential Pathogenic Bacteria}

To reveal the distribution of potential bacterial pathogens in the collected samples, we limited further analysis to pathogenic bacteria that are typically associated with human diseases. Namely the data was pruned for bacteria of the Enterobacteriaceae, Bacillaceae, Chlamydiaceae, Helicobacteraceae, Neisseriaceae, Pseudomonadaceae, Streptococcaceae, Staphylococcaceae, Mycoplasmataceae and Vibrionacea families $[10,26]$. Because not all genera within these families are considered to be pathogens, we further focused the analysis on pathogenic bacterial genera within these families. Altogether, 576 ASVs comprised of 51 genera of potentially pathogenic bacteria were identified. Pathogens, like Salmonella enterica, Klebsiella pneumonia, Vibrio cholera, Helicobacter rodentia and others, were identified in our dataset in a relatively small number of samples (Figure 3B, Supporting Datasheet "Rarefied Taxa"). The relative abundance and diversity of these types of bacteria appear to be significantly lower in SW samples than in FW samples (Figure 3A, SI Figure S1), an observation that is consistent with the fact that most of these bacteria are terrestrial and not marine. 
A Moraxellaceae

Pseudomonadaceae

Arcobacteraceae

Enterobacteriaceae

Vibrionaceae

Bacillaceae

Legionellaceae

Neisseriaceae

Mycoplasmataceae

Paenibacillaceae

Others

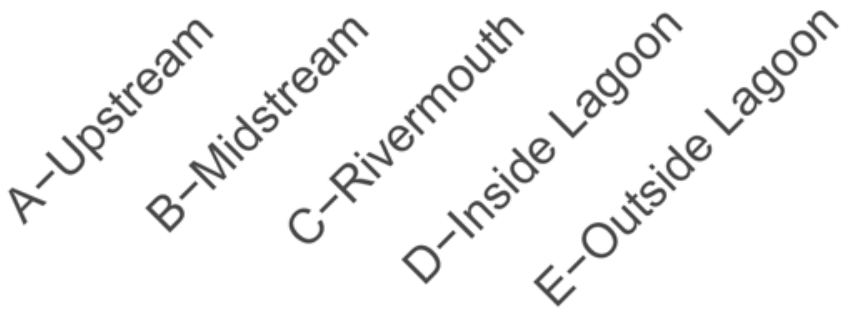

Figure 3. Cont. 
B

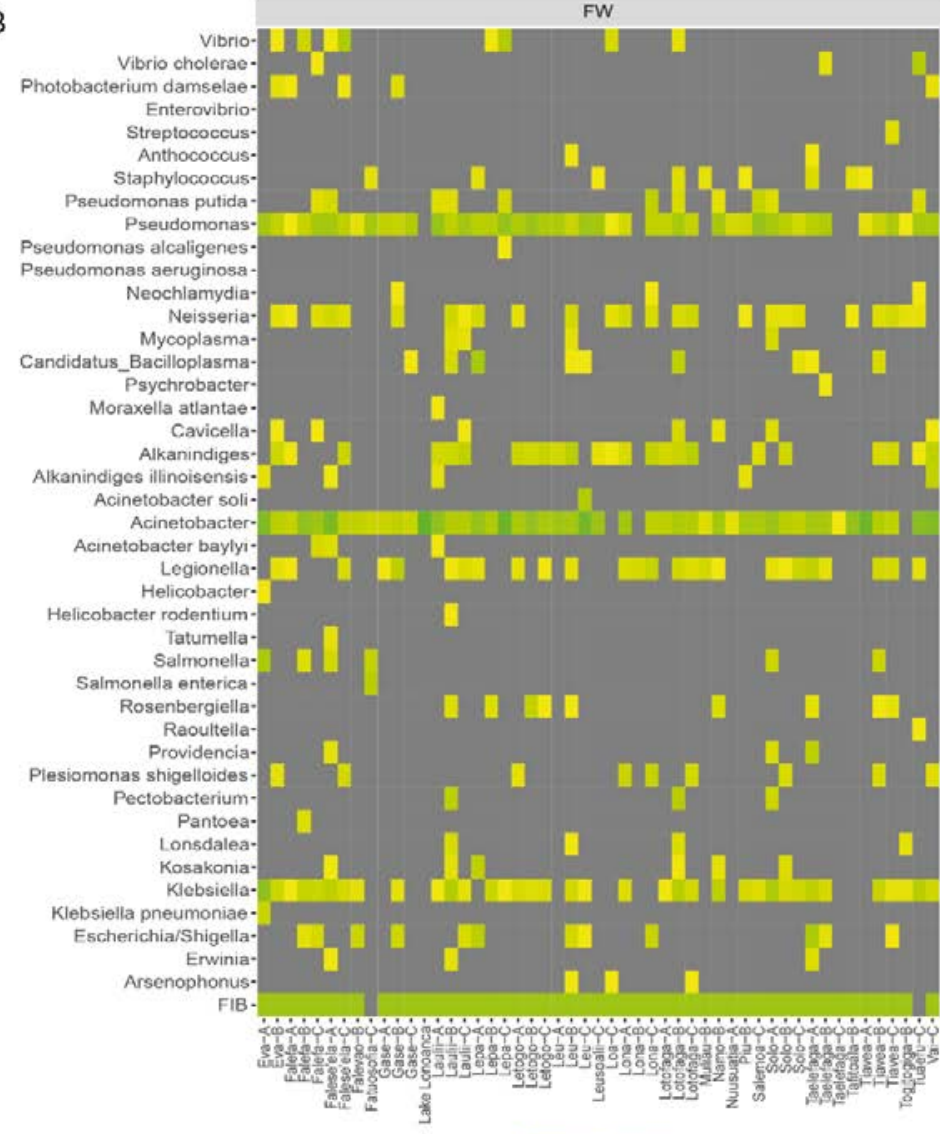

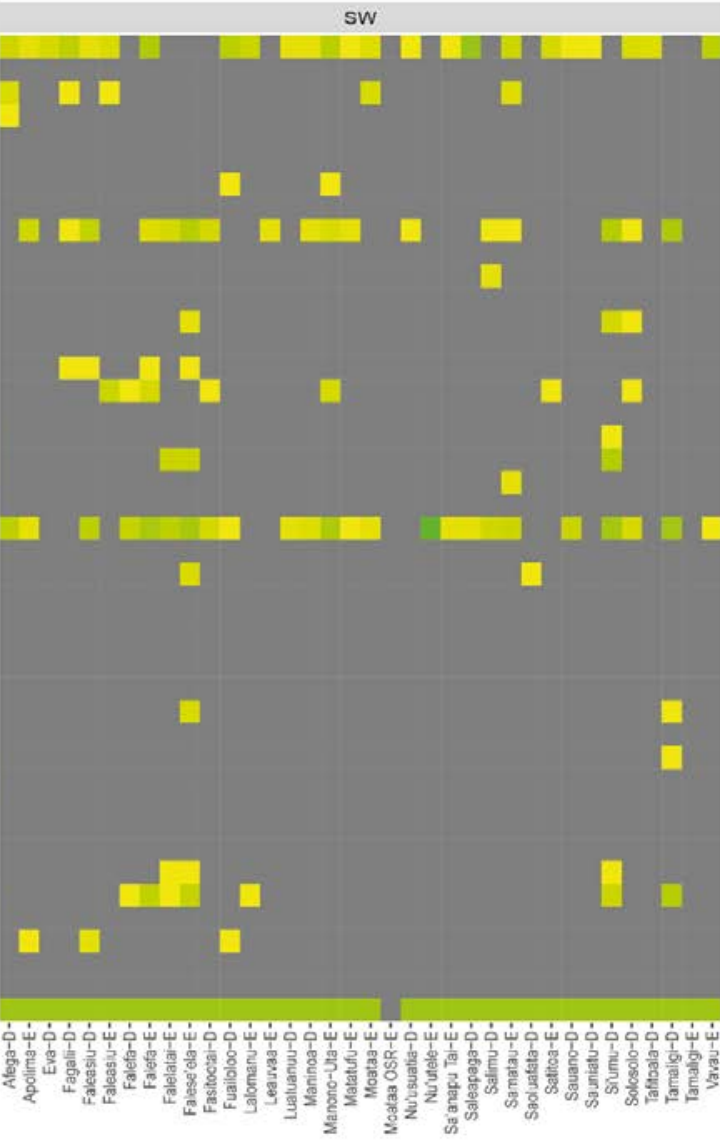

$0 \quad 1 \quad 2 \quad 3$

Figure 3. (A) Comparison of ASVs belonging to species and genera of potentially pathogenic bacteria at family level at the 5 sampling sites, Upstream-A $(n=15)$, Midstream-B $(n=18)$, Rivermouth-C $(n=21)$, Inside-D $(n=18)$ and Outside lagoon-E $(n=16)$. Abundance of the individual bacterial is normalized for sites (circle size) and log10 total reads are color coded. (B) Heatmap showing the presence of FIB, $\log _{10}$ read abundance (yellow $=1-10$ reads, green $=1000+$ reads) and prevalence of ASVs that belong to potentially pathogenic bacteria at the species and genus levels for individual sampling sites grouped into FW and SW.

FW samples were dominated by ASVs that may be considered pathogens, such as Moraxellcea, Enterobacteriaceae and, at the rivermouth, Bacillaceae families. Nearly all FW samples showed the presence of ASVs belonging to Pseudomonas spp., Acinetobacter spp., or Enterobacter spp. (Figure 3B). SW samples within the lagoon were rich in ASVs that belong to Vibrionaceae, Moraxellaceae and Enterobacteriaceae, whereas outside the lagoon, ASVs belonging to Moraxellacea dominated. In contrast, SW samples showed lower abundance of ASVs belonging to Enterobacteriaceae but a wider distribution of ASVs belonging to Vibrio spp. (Figure 3B) than in FW. A strong correlation was observed between the FIB results and the distribution of ASVs belonging to pathogens and potential pathogens (Figure 3B). Although FIB was nearly ubiquitous in most samples (84/88) based on the Colilert kit, successful detection of $E$. coli by amplicon sequencing showed less ubiquity (26/88). Despite this discrepancy, ASVs potentially belonging to other pathogenic Enterbacteriacea were found in 76 of 88 samples. Pearson correlation between the presence of FIB, E. coli, Enterobacteriaceae and potential pathogenic bacteria at different sites only showed significant correlation between the presence of E. coli and Enterobacteriacea ( $p$-value: 0.011, SI Figure S2).

These four most abundant ASVs belonging to the potentially pathogenic bacterial genera Escherichia, Plesiomonas, Staphylococcus, and Klebsiella were spread widely on Upolu Island (Figure 4). Putative contamination hotspots for E. coli and Plesiomonas spp. are located in the northeastern parts of Upolu, between Apia and Tiavea (Figure 4A,B). 
In contrast, ASVs belonging to Staphylococcus and Klebsiella spp. have been detected all around the island (Figure 4C,D). Many other potentially pathogenic microbial genera may be present around population hotspots. ASVs belonging to these groups included $A r-$ senophonus sp., Catellicoccus sp., Morganella sp., Providencia sp., Raoultella sp. and Salmonella sp. and were mainly found in the vicinity of Apia, Tiavea, Sataoauta, Falene'sela and Faleasiu (SI Figure S4A-F).
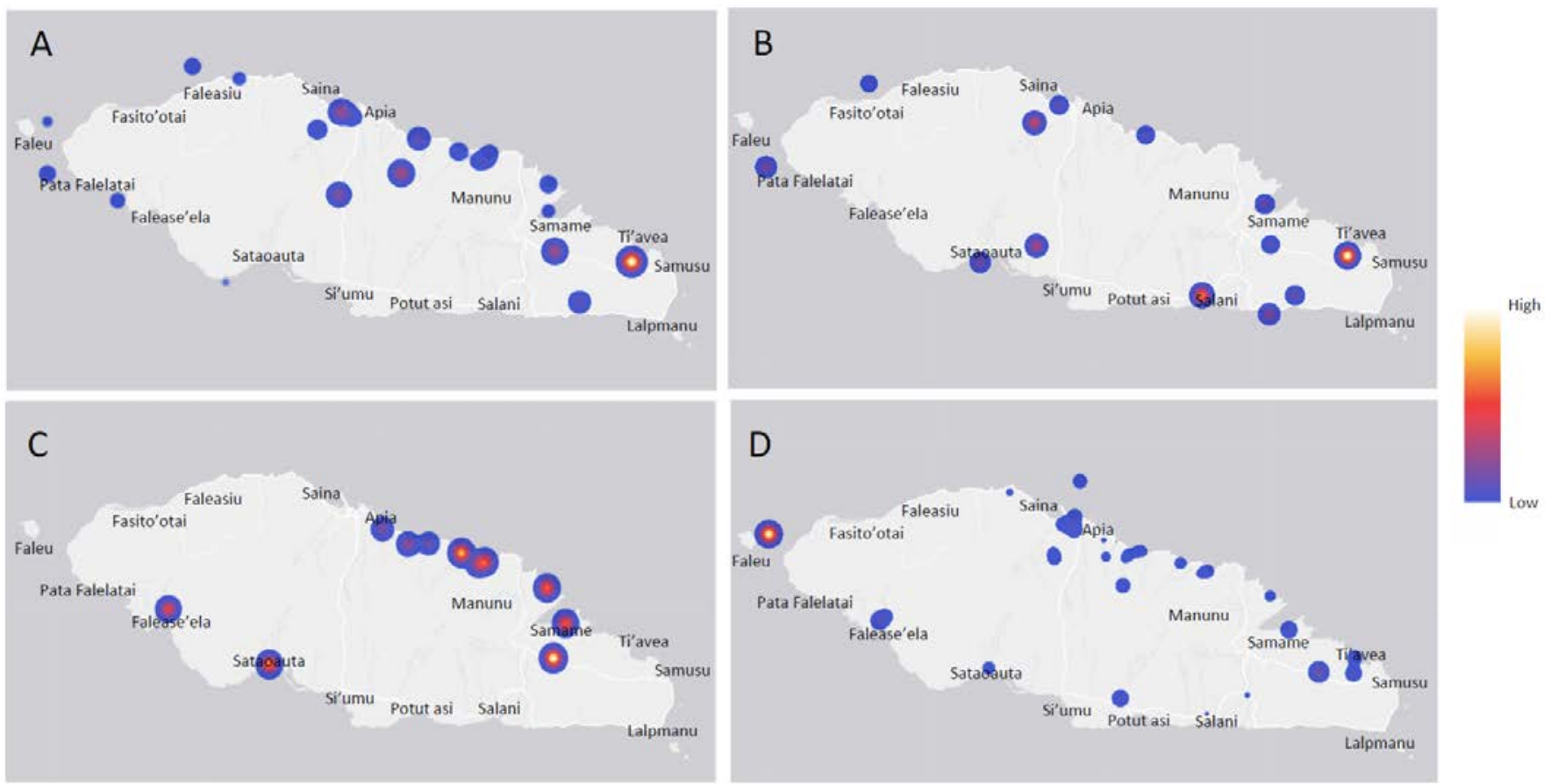

Figure 4. Overview of distribution of ASVs belonging to four potentially pathogenic bacterial genera around Upolu Island based on amplicon sequencing. ArcGIS Distribution maps were overlaid with 16S rRNA total read abundance (dot size). Gradient color of each dot represent relative abundance of ASVs (blue = low; yellow = high) for Escherichia sp. (A), Staphylococcus sp. (B), Pleisomonas sp. (C), and Klebsiella sp. (D).

\section{Discussion}

By sampling river systems from upstream to downstream collection points and seawater samples within and outside the barrier reef lagoon of Upolu, we were able to potentially trace the points of origin of the contamination to these ecosystems. Physicochemical parameters, such as $\mathrm{pH}, \mathrm{DO}, \mathrm{ORP}$, nitrate and salinity, show relatively average values for FW and SW samples that conform to most other environments. The $\mathrm{pH}$ values ranged from 6.6-8.3, which is within the guidelines for suitable drinking water [25,27]. The DO ranges of most samples conform to the norm for environmental water bodies and indicate normal oxic levels in freshwater [28]. The low DO values that were found at the Gasegase site, Falefa sites B and C and Afulilo Dam may indicate stagnant or contaminated waters; while further monitoring is needed to confirm these observations, they might indicate organic pollution. Within the mentioned measurement limitations (M\&M), ORP values also suggest that most waterbodies contain enough oxidation potential for the biochemical degradation of contaminants and can be viewed as healthy.

Freshwater bacterial communities commonly have higher diversity than marine water because of the wide variety of terrestrial fauna, flora and geography [29], whereas SW samples are influenced by the more microbial homogenous open ocean. For both FW and SW we found that characteristic communities mainly consist of Proteobacteria, Bacteriodetes and Actinobacteria, but are low in numbers of Firmicutes, which are generally found in high abundance in freshwater samples [29-32]. This is likely a result of the sampling being done from the surface of moving waterbodies, as Firmicutes are mainly found in sediments 
and on particulates [31]. For SW samples, we observed a significant drop in diversity at the salinity gradient of river mouths, as these form a natural barrier [33].

FIBs are a good indicator for fecal contamination and virtually "none" of the water samples were free of FIB. The presence of E. coli in upstream samples may be caused by feces from farm animals or human waste from potentially leaking septic tanks or sewage pipes. Notably, in contrast to temperate environments where the presence of E. coli is directly a byproduct of contamination from anthropogenic activities, tropical environments, such as Samoa, exhibit higher presence of $E$. coli that may or may not be correlated with anthropogenic activities or ecosystem contamination [34,35]. In addition to this caveat, although the presence of $E$. coli is ubiquitous throughout nearly all FW samples, not all E. coli strains are pathogenic, and high cell numbers need to be ingested for it to be infectious. Conversely, according to WHO guidelines, freshwater sources reaching the distribution system for human consumption or personal use should not contain any coliform bacteria in a $100 \mathrm{~mL}$ sample of freshwater [25]. Compared to previous studies which concentrated on three river systems, namely Fuluasou, Gasegase and Loimata o Apaula (LoA), our measurements are consistent with the ubiquity of these bacteria. In one study, it was reported that these rivers contain extremely high numbers of coliforms (>1000 cells $/ 100 \mathrm{~mL}$ ) [36]. Together, observations from this study and older studies suggest that careful examination of the freshwater sources of Upolu Island need to be undertaken in order to ensure drinking water is safe to consume throughout the year.

The sampling of the SW samples around Samoa showed widespread presence of coliform and E. coli, which were likely caused by the influx of runoff from rivers and waste water. Even at offshore locations $(<20 \mathrm{~km})$, our data suggest such bacteria were still present. In a recent study in the island nation of Tuvalu, high counts ( $>1000$ cells $/ 100 \mathrm{~mL})$ of $E$. coli were also found within the saltwater lagoon of its atoll [15]. These observations suggest a constant flow of microbial contaminants that accumulate within the barrier reef and survive because of high nutrient bioavailability [37] or biofilm formation on plastic debris [38,39].

The combined use of modern next-generation sequencing techniques and traditional FIB analysis identified a wide range of potential pathogens in most water bodies. While high sensitivity detection of FIB using the Colilert kit outperformed the sequencing approach, the kit cannot indicate the type(s) of Enterobacteriaceae or other widespread pathogens that are not detected by the kit. In contrast, amplicon sequencing can provide semi-quantitative information about bacterial diversity while providing a broad overview of bacteria that belong to genera considered to be pathogens. However, a common problem of short amplicon Illumina (e.g., MiSeq 250) sequencing approaches is that typically genuslevel identification is achieved, which is not enough to confirm beyond doubt the presence or absence of pathogenic candidates. Although we were able to identify some ASVs down to the species level (Figure 4), further work is needed to confirm if such bacteria are indeed pathogenic.

Despite the drawbacks of $16 \mathrm{~S}$ rRNA amplicon sequencing, we still identified various potentially concerning bacteria in Samoan waters. Apart from E. coli, other common waterborne pathogens that appeared in national disease outbreaks were identified. For example, Streptococcus spp., Pseudomonas aeruginosa, Klebsiella spp. and Pantoea spp. cause increased cases of pneumonia from water/mist aspiration, as demonstrated after the 2009 earthquake and Tsunami in Samoa [10]. These pathogens, especially Pseudomonas spp. and Klebsiella spp., are, according to our results, widely distributed throughout Upolu Island (Figure 4) and should therefore be a focus for any biosafety efforts. Pleisomonas spp. can also lead to a wide range of intestinal symptoms and skin and wound infections [40]. The pathogenic species $S$. aureus was detected in one in six FW samples; this bacterium can lead to wound and blood infections, and has the ability to acquire antibiotic resistance (e.g., MRSA), presenting a major threat in areas with lower health system standards [41,42]. A recent study of impetigo infections in school children of the Faleaili district in south Samoa reported a $57.1 \%$ infection rate in children that coincided with Staphylococci contaminated sites 
(Figure 3B), namely Lotofaga and Taofatila [43]. These high incidence rates of infections suggest an endemic issue that is partially supported by our findings.

Although it is challenging to test all rivers and water catchments, even for a small island like Upolu, we can approximate from the spatial coverage of our study that most water bodies of Upolu Island contain bacteria that may be pathogenic to some extent. Therefore, natural untreated freshwater resources should be used with caution until further work establishes if treatment is necessary. The previous work by Amosa et al. 2016 [16] already detected elevated levels of coliform bacteria throughout the year in two river systems close to highly populated areas; our data support this finding. Although high-cost FIB tests do not correlate strongly with sequencing-based approaches for the detection of other enterobacteria, as shown here and in other studies [18], our findings suggests that water bodies testing positive for E. coli will likely contain other bacterial pathogens, as shown by amplicon sequencing. Therefore, we suggest that using FIB kits can be helpful to verify and even quantify [15] contaminants for water management efforts, but specific pathogen identification, such as detecting and quantifying biomarkers of pathogenicity should be considered to trace contaminant sources and decide on the best approach for remediation [44,45].

Water safety is becoming a significant issue for remote tropical islands in the face of climate change, owing to more frequent and severe natural disasters [46]. More frequent storms lead to the mixing of contaminated water sources and overflowing septic tanks. The impact of pathogenic bacterial contaminations in water resources represents a great financial and social cost, and therefore has to be taken seriously for the protection of humans and nature. Water management and monitoring efforts have to be increased. Next to continuous monitoring and management efforts new simple, versatile and cheap techniques have to be developed to allow nations and regions with poorer economies to take control of their water resources.

Supplementary Materials: The following are available online at https://www.mdpi.com/article/ 10.3390/environments8110112/s1, Supporting info: Figure S1: Hierarchical clustering of $16 \mathrm{~S}$ data, Figure S2: Diversity of potential pathogenic Bacteria, Table S1: Details for FW samples, Table S2: Details for SW, Figure S3: Correlation Matrix of harmful Bacteria, Figure S4: Distribution of additional high abundance potentially pathogenic bacteria. Supporting data excel sheet (DADA2 statistics, rarefied taxons, SW and FW parameters).

Author Contributions: M.A.O. and C.F. processed the samples; M.A.O. analyzed and interpreted the data; M.A.O. and S.A.A. wrote the article; O.B. and Y.I. undertook the GIS mapping; E.R. provided logistical and GIS support; P.A. and G.G. provided logistical and administrative support; M.A.O. and T.G.B. performed water quality assessments. All authors have read and agreed to the published version of the manuscript.

Funding: This work was funded by the United Nations Development Program (UNDP) in Samoa to S.A.A. and T.G.B. (grant \# 00118217) and by NYU Abu Dhabi grant to S.A.A. (AD179).

Institutional Review Board Statement: Not applicable.

Informed Consent Statement: Not applicable.

Data Availability Statement: Sequencing results are deposited on NCBI GenBank accession number PRJNA773854.

Acknowledgments: The authors wish to thank the UN Resident Coordinator, Simona Marinescu, and her office team in Samoa for their excellent support and all required arrangements. Members of the Samoan Ministry of Natural Resources and Environment and faculty and students of the National University of Samoa, as well as AquaSamoa, provided all vehicles and logistical support for the project. This research was partially carried out using the Core Technology Platforms resources at New York University Abu Dhabi.

Conflicts of Interest: The authors declare no conflict of interest. 


\section{References}

1. Nada Osseiran, W.; Yemi Lufadeju, U. 1 in 3 People Globally Do not Have Access to Safe Drinking Water-UNICEF. WHO. 2019. Available online: https:/ / www.who.int/news/item/18-06-2019-1-in-3-people-globally-do-not-have-access-to-safe-drinkingwater-unicef-who (accessed on 10 May 2021).

2. Wear, S.L.; Thurber, R.V. Sewage pollution: Mitigation is key for coral reef stewardship. Ann. N. Y. Acad. Sci. 2015, 1355, 15-30. [CrossRef] [PubMed]

3. Murphy, E.A.; Post, G.B.; Buckley, B.T.; Lippincott, R.L.; Robson, M.G. Future challenges to protecting public health from drinking-water contaminants. Annu. Rev. Public Health 2012, 33, 209-224. [CrossRef] [PubMed]

4. Hancock, G.J.; Webster, I.T.; Stieglitz, T.C. Horizontal mixing of Great Barrier Reef waters: Offshore diffusivity determined from radium isotope distribution. J. Geophys. Res. Ocean. 2006, 111, 1-14. [CrossRef]

5. Leonard, A.F.C.; Singer, A.; Ukoumunne, O.C.; Gaze, W.H.; Garside, R. Is it safe to go back into the water? A systematic review and meta-analysis of the risk of acquiring infections from recreational exposure to seawater. Int. J. Epidemiol. 2018, 47, 572-586. [CrossRef]

6. Rabieh, S.; Bayaraa, O.; Romeo, E.; Amosa, P.; Calnek, K.; Idaghdour, Y.; Ochsenkühn, M.A.; Amin, S.A.; Goldstein, G.; Bromage, T.G. MH-ICP-MS Analysis of the Freshwater and Saltwater Environmental Resources of Upolu Island, Samoa. Molecules 2020, 25, 4871. [CrossRef]

7. Liu, J.; Chen, X.; Shu, H.; Lin, X.; Zhou, Q.; Bramryd, T.; Shu, W.; Huang, L. Microbial community structure and function in sediments from e-waste contaminated rivers at Guiyu area of China. Environ. Pollut. 2018, 235, 171-179. [CrossRef]

8. Varol, M.; Şen, B. Assessment of nutrient and heavy metal contamination in surface water and sediments of the upper Tigris River, Turkey. Catena 2012, 92, 1-10. [CrossRef]

9. Whitehead, P.G.; Wilby, R.L.; Battarbee, R.W.; Kernan, M.; Wade, A.J. A review of the potential impacts of climate change on surface water quality. Hydrol. Sci. J. 2009, 54, 101-123. [CrossRef]

10. Leong-nowell, T.A.; Leavai, F.; Ching, L.A.; Fiu, L.; Nisbet, M.; Jones, D.; Blackmore, T.; Ioane-cleverley, T. Aspiration pneumonia and challenges following the Samoa Tsunami in 2009. N. Z. Med. J. 2012, 125, 70-78.

11. Sikorski, M.J.; Desai, S.N.; Tupua, S.; Thomsen, R.E.; Han, J.; Rambocus, S.; Nimarota-Brown, S.; Punimata, L.; Tusitala, S.; Sialeipata, M.; et al. Tenacious endemic typhoid fever in Samoa. Clin. Infect. Dis. 2020, 71, S120-S126. [CrossRef] [PubMed]

12. Paul, J.H.; Rose, J.B.; Brown, J.; Shinn, E.A.; Miller, S.; Farrah, S.R. Viral tracer studies indicate contamination of marine waters by sewage disposal practices in Key Largo, Florida. Appl. Environ. Microbiol. 1995, 61, 2230-2234. [CrossRef]

13. Richards, S.; Paterson, E.; Withers, P.J.A.; Stutter, M. Septic tank discharges as multi-pollutant hotspots in catchments. Sci. Total Environ. 2016, 542, 854-863. [CrossRef]

14. Griffin, D.W.; Gibson, C.J.; Lipp, E.K.; Riley, K.; Paul, J.H.; Rose, J.B. Erratum: Detection of viral pathogens by reverse transcriptase PCR and of microbial indicators by standard methods in the canals of the Florida keys. Appl. Environ. Microbiol. 2000, 66, 876. [CrossRef]

15. Fujita, M.; Suzuki, J.; Sato, D.; Kuwahara, Y.; Yokoki, H.; Kayanne, H. Anthropogenic impacts on water quality of the lagoonal coast of Fongafale Islet, Funafuti Atoll, Tuvalu. Sustain. Sci. 2013, 8, 381-390. [CrossRef]

16. Amosa, P.; Imo, T.; Latu, F.; Vaurasi, V. Microbiological Assessment of River Water Quality in Samoa. Int. J. Sci. Res. 2016, 5, 225-234.

17. Wade, T.J.; Pai, N.; Eisenberg, J.N.S.; Colford, J.M. Do U.S. Environmental Protection Agency water quality guidelines for recreational waters prevent gastrointestinal illness? A systematic review and meta-analysis. Environ. Health Perspect. 2003, 111, 1102-1109. [CrossRef] [PubMed]

18. Harwood, V.J.; Levine, A.D.; Scott, T.M.; Chivukula, V.; Lukasik, J.; Farrah, S.R.; Rose, J.B. Validity of the indicator organism paradigm for pathogen reduction in reclaimed water and public health protection. Appl. Environ. Microbiol. 2005, 71, 3163-3170. [CrossRef] [PubMed]

19. Callahan, B.J.; Wong, J.; Heiner, C.; Oh, S.; Theriot, C.M.; Gulati, A.S.; McGill, S.K.; Dougherty, M.K. High-throughput amplicon sequencing of the full-length 16S rRNA gene with single-nucleotide resolution. bioRxiv 2018, 47, e103. [CrossRef]

20. Pruesse, E.; Quast, C.; Knittel, K.; Fuchs, B.M.; Ludwig, W.; Peplies, J.; Glöckner, F.O. SILVA: A comprehensive online resource for quality checked and aligned ribosomal RNA sequence data compatible with ARB. Nucleic Acids Res. 2007, 35, 7188-7196. [CrossRef]

21. McMurdie, P.J.; Holmes, S. Phyloseq: An R Package for Reproducible Interactive Analysis and Graphics of Microbiome Census Data. PLoS ONE 2013, 8, e61217. [CrossRef]

22. Dixon, P. Computer program review VEGAN, a package of R functions for community ecology. J. Veg. Sci. 2003, 14, 927-930. [CrossRef]

23. Wickham, H. ggplot2: Elegant Graphics for Data Analysis; Springer: New York, NY, USA, 2016; ISBN 978-3-319-24277-4.

24. Ondov, B.D.; Bergman, N.H.; Phillippy, A.M. Interactive metagenomic visualization in a Web browser. BMC Bioinform. 2011, 12, 385. [CrossRef]

25. WHO. Guidelines for Drinking-Water Quality; WHO: Geneva, Switzerland, 2011; Volume 1.

26. Hazen, T.C. Fecal coliforms as indicators in tropical waters: A review. Toxic. Assess. 1988, 3, 461-477. [CrossRef]

27. Anderson, D.A.; Armstrong, R.A.; Weil, E. Hyperspectral sensing of disease stress in the Caribbean reef-building coral, Orbicella faveolata-Perspectives for the field of coral disease monitoring. PLoS ONE 2013, 8, e81478. [CrossRef] 
28. Horne, A.J.; Goldman, C.R. Limnology; McGraw-Hill: New York, NY, USA, 1994.

29. Lee, S.-Y.; Eom, Y.-B. Analysis of Microbial Composition Associated with Freshwater and Seawater. Biomed. Sci. Lett. 2016, 22, 150-159. [CrossRef]

30. Hahn, M.W. The microbial diversity of inland waters. Curr. Opin. Biotechnol. 2006, 17, 256-261. [CrossRef] [PubMed]

31. Lemke, M.J.; Lienau, E.K.; Rothe, J.; Pagioro, T.A.; Rosenfeld, J.; Desalle, R. Description of freshwater bacterial assemblages from the Upper Paraná River floodpulse system, Brazil. Microb. Ecol. 2009, 57, 94-103.

32. Humbert, J.F.; Dorigo, U.; Cecchi, P.; Le Berre, B.; Debroas, D.; Bouvy, M. Comparison of the structure and composition of bacterial communities from temperate and tropical freshwater ecosystems. Environ. Microbiol. 2009, 11, 2339-2350. [CrossRef] [PubMed]

33. Hancock, J.T. Redox-Mediated Signal Transduction: Methods and Protocols; Humana Press: Totowa, NJ, USA, 2008; Volume 476, ISBN 9781588298423.

34. Rochelle-Newall, E.; Nguyen, T.M.H.; Le, T.P.Q.; Sengtaheuanghoung, O.; Ribolzi, O. A short review of fecal indicator bacteria in tropical aquatic ecosystems: Knowledge gaps and future directions. Front. Microbiol. 2015, 6, 1-15. [CrossRef] [PubMed]

35. Winfield, M.D.; Groisman, E.A. Role of nonhost environments in the lifestyles of Salmonella and Escherichia coli. Appl. Environ. Microbiol. 2003, 69, 3687-3694. [CrossRef] [PubMed]

36. Faiilagi, S.A. Assessing the impacts of land use patterns on river water quality at catchment level: A Case Study of Fuluasou River Catchment in Samoa. Master's Thesis, Massey University, Palmerston North, New Zealand, 2015.

37. Fabricius, K.E. Effects of terrestrial runoff on the ecology of corals and coral reefs: Review and synthesis. Mar. Pollut. Bull. 2005, 50, 125-146. [CrossRef] [PubMed]

38. Keswani, A.; Oliver, D.M.; Gutierrez, T.; Quilliam, R.S. Microbial hitchhikers on marine plastic debris: Human exposure risks at bathing waters and beach environments. Mar. Environ. Res. 2016, 118, 10-19. [CrossRef] [PubMed]

39. Hughes, T.P.; Anderson, K.D.; Connolly, S.R.; Heron, S.F.; Kerry, J.T.; Lough, J.M.; Baird, A.H.; Baum, J.K.; Berumen, M.L.; Bridge, T.C.; et al. Spatial and temporal patterns of mass bleaching of corals in the Anthropocene. Science 2018, 359, 80-83. [CrossRef]

40. Wu, D.C.; Chan, W.W.; Metelitsa, A.I.; Fiorillo, L.; Lin, A.N. Pseudomonas skin infection: Clinical features, epidemiology, and management. Am. J. Clin. Dermatol. 2011, 12, 157-169. [CrossRef] [PubMed]

41. Chambers, H.F. The changing epidemiology of staphylococcus aureus? Emerg. Infect. Dis. 2001, 7, 178-182. [CrossRef] [PubMed]

42. Lowy, F.D. Staphylococcus Aureus Infections. N. Engl. J. Med. 1998, 339, 520-532. [CrossRef]

43. Taiaroa, G.; Matalavea, B.; Tafuna, M.; Lacey, J.A.; Price, D.J.; Isaia, L.; Leaupepe, H.; Viali, S.; Lee, D.; Gorrie, C.L.; et al. The Lancet Regional Health-Western Pacific Scabies and impetigo in Samoa: A school-based clinical and molecular epidemiological study. Lancet Reg. Health West. Pacific 2021, 6, 100081. [CrossRef]

44. Motlagh, A.M.; Yang, Z. Detection and occurrence of indicator organisms and pathogens. Water Environ. Res. 2019, 91, 1402-1408. [CrossRef]

45. Tan, B.F.; Ng, C.; Nshimyimana, J.P.; Loh, L.L.; Gin, K.Y.H.; Thompson, J.R. Next-generation sequencing (NGS) for assessment of microbial water quality: Current progress, challenges, and future opportunities. Front. Microbiol. 2015, 6, 1027. [CrossRef] [PubMed]

46. Rupic, M.; Wetzell, L.; Marra, J.J.; Salwani, S. 2014-2016 El Niño Assessment Report: An Overview of the Impacts of the 2014-16 El Niño on the U.S.-Affiliated Pacific Islands (USAPI); National Oceanic and Atmospheric Administration: Washington, DC, USA, 2018; p. 48 . 